\title{
MUSCLE WEAKNESS ASSESSMENT IN OLDER INTENSIVE CARE UNIT PATIENTS
}

\author{
Avaliação da fraqueza muscular de idosos \\ hospitalizados em uma unidade de terapia intensiva
}

\author{
Amanda Colombo Peteck Lopes ${ }^{\circledR}$, Paulo Henrique Coltro $\bullet$, Vagner José Lopes ${ }^{\mathrm{C}}$,

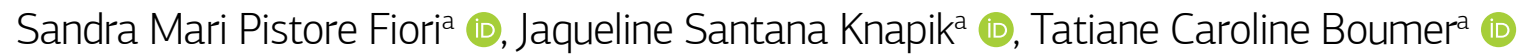

INTRODUCTION: After long periods of hospitalization, older adults may develop muscle weakness that can affect their functional independence after discharge. OBJECTIVE: To assess muscle weakness in older patients admitted to an ICU. METHOD: This cross-sectional, descriptive study with a quantitative approach assessed functional independence with the Katz Index and post-ICU muscle strength with a handgrip strength (HS) test and the Medical Research Council (MRC) sum-score. The sample consisted of 60 patients with an average age of 76 (60-99) years, 36 (60\%) of whom were female. RESULTS: Post-ICU, 86.7\% of the patients were functionally dependent. Female patients had significantly lower HS than males: 7 (0-24) vs. 17 (1-37) (p $<0.001)$. Female patients who received mechanical ventilation (MV) or sedation had significantly lower HS and MRC scores than those who did not ( $<$ 0.001): HS MV 1 (0-13) vs. 11 (0-24) p < 0.001; MRC MV 35 (14-48) vs. 43 (27-57) p<0.001; HS sedation 0 (0-12) vs. 9 (0-24) p < 0.001; MRC sedation 34 (14-36) vs. 42 (22-57) p < 0.001, respectively. Finally, there was an inversely proportional correlation between HS, MRC scores, and ICU length of stay, Spearman's rho $=-0.267(p=0.0039)$ and Spearman's rho $=-0.347(p=0.007)$, respectively. CONCLUSION: Older women who received mechanical ventilation and sedation have lower muscle strength than those who did not. As the ICU length of stay increases, muscle strength decreases.

KEYWORDS: older adults; muscle weakness; hospitalization; intensive care unit.

INTRODUÇÃO: Após longos períodos de internação, o idoso pode desenvolver fraqueza muscular que pode impactar sua independência funcional pós-hospitalização. OBJETIVO: Avaliar a presença de fraqueza muscular em pacientes idosos internados em uma unidade de terapia intensiva (UTI). METODOLOGIA: Trata-se de um estudo transversal, descritivo, de abordagem quantitativa, que avaliou a funcionalidade por meio do questionário Índice de Katz (IK), a força muscular pós-hospitalização em UTI por meio da força de preensão manual (FPM) e pelo Medical Research Council (MRC). A amostra foi composta de 60 pacientes com idade mediana de 76 (60-99) anos. Destes, 36 (60\%) eram do gênero feminino e 24 (40\%) do masculino. RESULTADOS: Pós-UTI, 86,7\% dos idosos apresentaram dependência funcional. Idosos do gênero feminino apresentaram FPM estatisticamente menores que as do gênero masculino, sete (0-24) vs. 17 (1-37) ( $<$ <,001). Idosas em uso de ventilação mecânica (VM) e sedação apresentaram FPM e MRC estatisticamente menores quando comparadas às que não fizeram uso desse recurso ( $p<0,001)$ : FPM VM 1 (0-13) vs. 11 (0-24) p < 0,001; MRC VM 35 (14-48) vs. 43 (27-57) p < 0,001; FPM sedação $0(0-12)$ vs. $9(0$ - 24) p < 0,001; MRC sedação 34 (14-36) vs. 42 (22-57) p < 0,001, respectivamente. Por fim, existe correlação inversamente proporcional e FPM e MRC e tempo de internamento na UTI, rô de Spearman =-0,267 ( $p=0,0039$ ) e rô = -0,347 ( $p=0,007$ ), respectivamente. CONCLUSÃO: Mulheres apresentaram redução da força muscular quando fizeram uso de VM e sedação, quando comparadas às que não fizeram. À medida que se aumenta o tempo de internação na UTI, mais a força muscular diminui.

PALAVRAS-CHAVE: idoso; debilidade muscular; hospitalização; unidade de terapia intensiva.

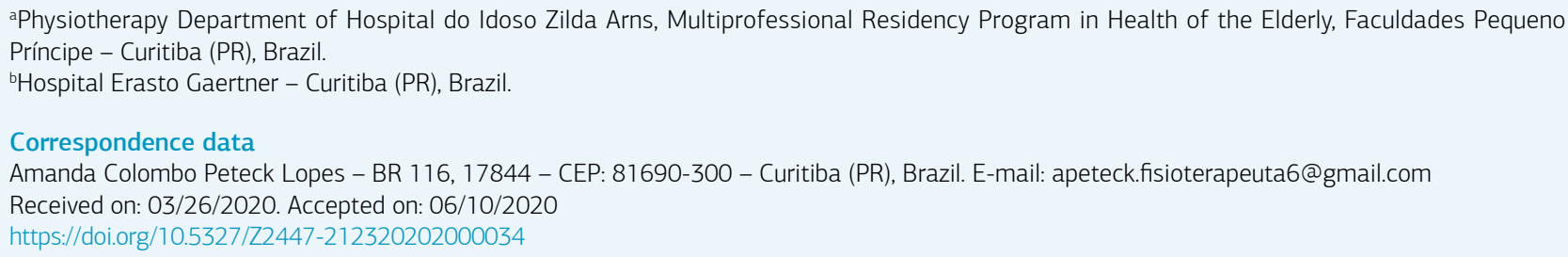




\section{INTRODUCTION}

Human aging is a physiological, multifactorial and natural process involving osteoarticular and proprioceptive changes that can result in the development of muscle weakness, sarcopenia, and osteopenia. ${ }^{1}$ With these changes, older adults are more vulnerable to developing diseases of insidious onset, such as those of the locomotor, cardiovascular, pulmonary, and metabolic systems, as well as mental disorders, which can result in hospitalization in inpatient units or even intensive care units (ICU). ${ }^{2}$

The ICU admits patients who are at imminent risk due to a vulnerable, frail, or inflammatory condition, requiring advanced treatment or even invasive technologies. These technologies provide benefits and can often help reverse disease, attenuate muscle weakness during hospitalization, ${ }^{3,4}$ or contribute to its development, which is called intensive care unit-acquired weakness (ICUAW) ${ }^{5,6}$

ICUAW is related to chronological characteristics and lifestyle habits, such as patient age, gender, body mass index, physical inactivity, dependence in activities of daily living, and low food consumption. ${ }^{6,7}$ That is, these characteristics can be determining factors in the prognosis of patients with ICUAW.

The prolonged use of mechanical ventilation (MV) and sedatives and bed restriction/or immobility accelerate the development of ICUAW. However, the evolution of ICUAW involves a vicious cycle since, despite being associated with the use of sedatives ${ }^{8}$ and longer time on $\mathrm{MV}$, it can also delay the withdrawal of MV or even cause extubation failure. ${ }^{8,9}$ As a result, new sepsis may appear, ${ }^{10}$ leading to decompensation and an exponential increase in bed restriction, which accelerates the development of ICUAW. ${ }^{11}$

The literature reports that muscle loss can occur early in an ICU stay and to a greater degree in individuals with systemic impairment. ${ }^{12}$ Another relevant consideration is that low handgrip strength (HS) in critically ill patients is associated with higher six-month mortality, longer ICU stays and more days on $\mathrm{MV} .{ }^{13}$ These unfavorable outcomes can have an economic impact on the health system, since muscle weakness associated with new infections can lead to a $58.5 \%$ increase in hospital expenses. ${ }^{14,15}$

Although some measures have been proposed to help reduce ICUAW, ${ }^{16}$ such as daily awakening ${ }^{17}$ and increased caloric intake, ${ }^{7}$ none have been proven efficacious in preventing its appearance. Therefore, an early, periodic assessment is perhaps the best option for quickly detecting ICUAW and achieving greater control over its effects after diagnosis. Since early identification could minimize the functional loss acquired during an ICU stay, the aim of this study was to assess the presence of muscle weakness in older ICU patients.

\section{METHODS}

This cross-sectional, descriptive study with a quantitative approach was conducted between April and September 2018 at the general ICU of a public hospital in Curitiba, Paraná, Brazil, which is a reference center for older adult care. The ICU sector has 20 beds for clinical and surgical admissions.

The study was approved by the Municipal Health Secretariat of Curitiba Research Ethics Committee (CEP/ SMS: 2,396,983). All patients or their family members provided written informed consent prior to participation. When this was impossible, the patient's companion provided written informed assent.

The convenience sample included patients aged at least 60 years whose ICU stay was over 24 hours and who could understand and respond to verbal and motor commands. The following patients were excluded: those with motor alterations, such as plegia and paralysis due to traumatic, neurological, and/or neurodegenerative injuries; those with upper limb amputations; those with untreated psychiatric illnesses; and those whose medical record included delirium.

Data collection was divided into two phases, the first during the ICU stay and the second 48 hours after ICU discharge. During ICU hospitalization, previous functional independence was assessed through the 1998 Katz Index of activities of daily living, modified by the Hartford Institute for Geriatric Nursing. ${ }^{18}$ For this assessment, a family member responded to questions about the patient's functionality in activities of daily living such as bathing, dressing, personal hygiene, fecal continence, and feeding. Total scores range from 0 to 6 points, with 5-6 points classified as independent, 3-4 points as moderately dependent, and $0-2$ points as dependent. ${ }^{19}$

A physical examination was performed 48 hours after ICU discharge, while the patient was in the inpatient unit. The KI was reapplied to determine any change in independence after ICU discharge.

To quantify muscle strength after ICU discharge, a $\mathrm{Jamar}^{\circledR}$ dynamometer was used to assess handgrip strength (HS). This device was sent to a laboratory accredited by the National Institute of Metrology, Quality and Technology (Inmetro) for calibration (certification: TDA1530-18) prior to data collection. To perform the test, the patient remained in bed in the supine position with 
the head elevated between $30^{\circ}$ and $45^{\circ}$ and the tested arm supported. The patient then squeezed the dynamometer with the dominant hand, performing a maximum isometric contraction for 5 seconds. Three attempts were made, with a one-minute interval between each attempt, and the highest score was used. Scores below $7 \mathrm{kgf}$ for women and $11 \mathrm{kgf}$ for men were considered indicative of ICUAW. ${ }^{10}$

The Medical Research Council (MRC) sum-score was used to assess muscle strength in the shoulder abductor, elbow flexor, wrist flexor, hip flexor, knee extensor and dorsiflexor muscle groups. For this test, the patients were placed in the supine position with the head elevated between $30^{\circ}$ and $45^{\circ}$. The upper limbs were tested before the lower limbs. To classify muscle strength, Kendall's scale (0 to 5) was used, with a maximum of 60 points. Muscle strength was divided into four categories according to total scores: preserved strength (48-60 points); peripheral weakness $(<48)$; significant weakness $(<30)$; and severe weakness $(<27) .{ }^{20}$

\section{Statistical analysis}

The collected data were compiled in an Excel spreadsheet, and all statistical analyses were performed in SPSS 21.0. The Kolmogorov-Smirnov test was used to assess data normality, and non-parametric analysis was used when non-normal distribution was found. Thus, the data are presented as median (minimum-maximum), with categorical variables presented as frequency distribution (percentages).

The following comparisons were made: sex and muscle strength (HS vs. MRC), MV (use vs. non-use) and muscle strength, and sedation (use vs. non-use) and muscle strength, all separated by sex. The Mann-Whitney non-parametric test was used for these analyses. The correlation between ICU length of stay and muscle strength after ICU discharge was also analyzed using the Spearman correlation test. A significance level of $95 \%(\bigotimes=0.05)$ was assumed for all analyses.

\section{RESULTS}

A total of 76 family members and/or patients were approached about inclusion. One patient refused to participate, eight were excluded for not meeting the inclusion criteria (one due to lower limb bone disease, three due to post-stroke plegia, three due to delirium, one could not respond to verbal or motor commands). Thus, 67 patients were initially included in the study.
Seven died during the investigation and were considered sample losses.

The final sample consisted of 60 participants, of whom 36 were women and 24 men. The other sample characteristics are shown in Table 1. Table 2 shows the frequency distributions of pre- and post-ICU independence levels. Table 3 shows muscle strength in male and female patients 48 hours after ICU discharge; there was a sex difference for HS, i.e., women had lower HS values than men. Table 4 shows the effects of MV and sedation on muscle strength according to sex.

As shown in Table 4, there was no difference in muscle strength between sexes among patients who did not receive sedation. However, for the other measures, women had significantly lower muscle strength than men. Another relevant finding is that sedation or MV had no effect on muscle strength in men. However, women who received MV or sedation had significantly lower muscle strength than those who did not.

Figure 1 shows the correlation between ICU length of stay and muscle strength. There was an inversely proportional correlation between ICU length of stay and muscle strength, i.e., the longer the ICU stay, the lower the muscle strength.

\section{DISCUSSION}

Although assessing muscle weakness in patients during ICU hospitalization is relevant, it is complex since it encompasses a number of factors (sleep and movement deprivation, pharmacological therapies, etc. $)^{21}$ that can lead to the development or accentuation of muscle weakness. In this study, the patients showed a loss of functional independence after hospitalization, making the independent or partially dependent patients dependent on other individuals to perform basic activities of daily living ( 86.7 and $68.3 \%$, respectively). This demonstrates the devastating impact that ICU hospitalization has on older adults, since many such patients become permanently dependent. ${ }^{22,23}$

Reduced functional capacity (dependent or moderately dependent) was present in only $31.1 \%$ of the included patients prior to hospitalization. Thus, these patients would be more likely to develop muscle weakness, since older adults with some frailty tend to become more limited after long periods of immobility and other conditions involved in the hospital environment. ${ }^{2,24}$

Despite impaired functionality, the men's handgrip strength remained higher than that of women. Another 
study ${ }^{25}$ found that older men had higher HS after hospitalization, unlike women, who were associated with low functional capacity. ${ }^{25}$ According to the literature, suggestive cutoff points for ICUAW are $7 \mathrm{kgf}$ for women and

Table 1 Sociodemographic and clinical characteristics of a sample of older ICU patients (Curitiba, PR, Brazil, 2020).

\begin{tabular}{|c|c|}
\hline Variables & Values \\
\hline $\begin{array}{l}\text { Age (years) } \\
\text { median (minimum-maximum) }\end{array}$ & 76 (60-99) \\
\hline \multicolumn{2}{|l|}{ Sex } \\
\hline Female n (\%) & $36(60 \%)$ \\
\hline Male n (\%) & $24(40 \%)$ \\
\hline \multicolumn{2}{|l|}{ Comorbidities } \\
\hline Pulmonary n (\%) & $18(30 \%)$ \\
\hline Cardiovascular n (\%) & $15(25 \%)$ \\
\hline Use of MV n (\%) & $27(45 \%)$ \\
\hline $\begin{array}{l}\text { Time on MV (days) } \\
\text { median (minimum-maximum) }\end{array}$ & $12(2-41)$ \\
\hline Use of sedation n (\%) & $17(28.3 \%)$ \\
\hline $\begin{array}{l}\text { Time on sedation (days) } \\
\text { median (minimum-maximum) }\end{array}$ & $4(1-14)$ \\
\hline $\begin{array}{l}\text { Length of ICU stay (days) median } \\
\text { (minimum-maximum) }\end{array}$ & $5(1-46)$ \\
\hline
\end{tabular}

$11 \mathrm{kgf}$ for men. ${ }^{10}$ Thus, only female patients had ICUAW in this study.

The reduced handgrip strength found among female patients could be related to the use of $\mathrm{MV} .{ }^{26}$ Table 4 shows

Table 2 Frequency distribution of independence level (Katz Index) in older patients pre- and post-ICU (Curitiba, PR, Brazil, 2020).

\begin{tabular}{l|c|c} 
Katz index & $\begin{array}{c}\text { Pre-ICU } \\
\text { n (\%) }\end{array}$ & $\begin{array}{c}\text { Post-ICU } \\
\text { n (\%) }\end{array}$ \\
\hline Dependent & $6(10 \%)$ & $52(86 \%)$ \\
\hline Moderately dependent & $13(22 \%)$ & $4(7 \%)$ \\
\hline Independent & $41(68 \%)$ & $4(7 \%)$
\end{tabular}

\%: relative frequency; $\mathrm{n}$ : absolute; $\mathrm{ICU}=$ intensive care unit.

Table 3 Muscle strength in older male and female ICU patients after ICU discharge (Curitiba, PR, Brazil, 2020).

\begin{tabular}{l|c|c|c|c}
\multirow{2}{*}{ Assessment } & \multicolumn{2}{|c|}{ Sex } & \multirow{2}{*}{ p-value } & Total \\
\cline { 2 - 3 } & Female & Male & & 10 \\
$\begin{array}{l}\text { Handgrip strength } \\
\text { (kg/f) median } \\
\text { (minimum- } \\
\text { maximum) }\end{array}$ & $\begin{array}{c}7 \\
(0-24)\end{array}$ & $\begin{array}{c}17 \\
(1-37)\end{array}$ & $<0.001^{*}$ & $\begin{array}{c}10-37) \\
(0-37)\end{array}$ \\
\hline $\begin{array}{l}\text { Medical Research } \\
\text { Council sum-score } \\
\text { (points) median } \\
\text { (minimum- } \\
\text { maximum) }\end{array}$ & $\begin{array}{c}36 \\
(14-57)\end{array}$ & $\begin{array}{c}42 \\
(19-58)\end{array}$ & 0.089 & $\begin{array}{c}38 \\
(14-58)\end{array}$ \\
\hline
\end{tabular}

*Statistically significant (Mann-Whitney test); ICU = intensive care unit.

Table 4 Muscle strength 48 hours after ICU discharge in older patients who did or did not receive mechanical ventilation or sedatives (Curitiba, PR, Brazil, 2020).

\begin{tabular}{|c|c|c|c|c|c|c|c|}
\hline \multirow{2}{*}{ Muscle strength assessment } & \multirow{2}{*}{\multicolumn{2}{|c|}{ Use of: }} & \multicolumn{4}{|c|}{ Sex } & \multirow{2}{*}{$\begin{array}{l}\text { p-value } \\
\text { between } \\
\text { sexes }\end{array}$} \\
\hline & & & Female & p-value & Male & p-value & \\
\hline \multirow{4}{*}{$\begin{array}{l}\text { Handgrip strength (kg/f) } \\
\text { median (minimum-maximum) }\end{array}$} & \multirow{2}{*}{ MV } & Yes & $1(0-13)$ & \multirow{2}{*}{$<0.001^{*}$} & $17(3-37)$ & \multirow{2}{*}{0.666} & $<0.001^{*}$ \\
\hline & & No & $11(0-24)$ & & $17(1-25)$ & & $<0.001^{*}$ \\
\hline & \multirow{2}{*}{ Sedation } & Yes & $0(0-12)$ & \multirow{2}{*}{$0.001^{*}$} & $20(3-37)$ & \multirow{2}{*}{0.177} & $0.001^{*}$ \\
\hline & & No & $9(0-24)$ & & $17(1-25)$ & & $0.023^{*}$ \\
\hline \multirow{4}{*}{$\begin{array}{l}\text { Medical Research Council } \\
\text { sum-score (points) } \\
\text { median (minimum-maximum) }\end{array}$} & \multirow{2}{*}{ MV } & Yes & $35(14-48)$ & \multirow{2}{*}{$<0.001^{*}$} & $43(36-52)$ & \multirow{2}{*}{0.752} & $<0.001^{*}$ \\
\hline & & No & $43(27-57)$ & & $40(19-58)$ & & $<0.001^{*}$ \\
\hline & \multirow{2}{*}{ Sedation } & Yes & $34(14-36)$ & \multirow{2}{*}{$0.001^{*}$} & $43(36-52)$ & \multirow{2}{*}{0.721} & $<0.001^{*}$ \\
\hline & & No & $42(22-57)$ & & $41(19-58)$ & & 0.951 \\
\hline
\end{tabular}

*Statistically significant (Mann-Whitney test); ICU = intensive care unit; MV: mechanical ventilation. 

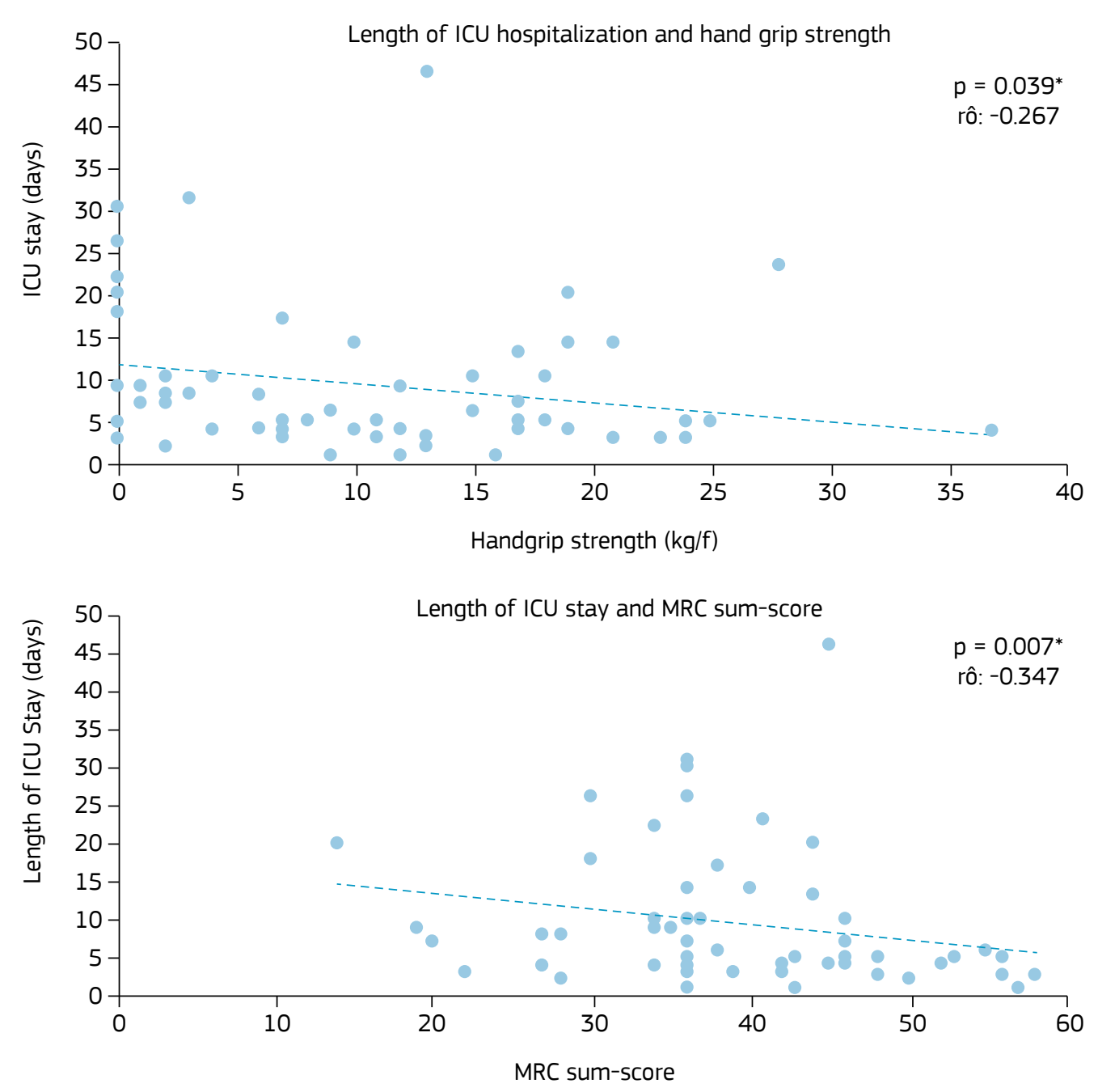

*statistically significant; ICU = intensive care unit; MRC = Medical Research Council.

Figure 1 Correlation between ICU length of stay and muscle strength in older adults, Curitiba PR, Brazil, 2020.

that more than $50 \%$ (median value) of older women who received $\mathrm{MV}$ and/or sedation presented subnormal (7 kgf) HS values and, thus, ICUAW. There are also reports in the literature about sex differences in muscle quality, with the average lower limb muscle volume much greater in men than women. ${ }^{24}$ This important muscle loss in women may be associated with the fact that that women have smaller muscle structures, including less protein mass in their muscle fibers and more intramuscular fat than men. ${ }^{24,27}$ These physiological characteristics can make older women more vulnerable to extrinsic factors that accelerate muscle loss.

There is evidence that peripheral muscle weakness may be associated with extubation failure and longer hospitalization and MV duration, since muscle strength can influence ventilatory weaning. That is, there is a higher risk of extubation failure in older patients with severe muscle weakness, ${ }^{28,29}$ and extubation failure and the use of sedatives have been associated with prolonged ICU stays and high mortality rates. ${ }^{9,30}$

The correlation between ICU length of stay and muscle weakness (Figure 1) indicates that prolonged periods in the ICU lead to reduced muscle strength. The literature ${ }^{31}$ reports that older people who remain hospitalized for more than 19 days are more affected by muscle atrophy than those who stay less than seven days. Although was this not assessed in our study, it is evident, since unfavorable outcomes in functional independence and muscle strength were found in patients with even shorter ICU stays. 


\section{CONCLUSION}

The muscle weakness found in older ICU patients is related to prolonged hospital stays and the use of MV and sedation. The muscle strength of female patients was much less than that of male patients, and the odds of developing muscle weakness increased with length of stay in the ICU. These findings could contribute to a better understanding of ICUAW.

\section{CONFLICT OF INTERESTS}

The authors declare no conflict of interest.

\section{FUNDING}

None.

\section{AUTHORS' CONTRIBUTION}

ACPL: created the idea for the scientific article by detecting the gaps and hypotheses of the present study. She structured the methodology of the article including all the tests used. She wrote the manuscript, resolving fundamental problems of the article, and she collected and statistically analyzed the data. The funds for this study were all financed by Amanda Colombo Peteck Lopes. PHC: guided and coordinated the group that carried out the research. He helped and guided the writing of the manuscript, and presented important suggestions that were incorporated into the work. He is the head of the physiotherapy deparment and is the advisor in the physiotherapy residency at the hospital where the data were collected. VJL: assisted and guided the writing of the manuscript, presented important suggestions that were incorporated into the work, and statistically analyzed the text. SMPF: helped and guided the writing of the manuscript, and presented important suggestions that were incorporated into the work. She is a professor in the physiotherapy residency at the hospital where the data were collected. JSK: helped and guided the writing of the manuscript, and presented important suggestions that were incorporated into the work. She assisted in giving guidance regarding the methodology, because she works at the unit where the research was collected and carried out. TCB: assisted in the writing of the manuscript, resolving fundamental problems of the article. She presented important suggestions that were incorporated into the work. Lastly, she guided the work and analyzed the statistics of the study.

\section{REFERENCES}

1. Pelegrini A, Mazo GZ, Pinto A de A, Benedetti TRB, Silva DAS, Petroski EL. Sarcopenia: prevalence and associated factors among elderly from a Brazilian capital. Fisioter Mov. 2018;31:1-8. http://dx.doi. org/10.1590/1980-5918.031.ao02

2. Carvalho TC, Valle AP do, Jacinto AF, Mayoral VF de S, Boas PJFV. Impact of hospitalization on the functional capacity of the elderly: A cohort study. Rev Bras Geriatr e Gerontol. 2018;21(2):134-42. http:// dx.doi.org/10.1590/1981-22562018021.170143

3. Hodgson CL, Tipping CJ. Physiotherapy management of intensive care unit-acquired weakness. J Physiother. 2017;63(1):4-10. http://dx.doi. org/10.1016/j.jphys.2016.10.011

4. Coker RH, Hays NP, Williams RH, Wolfe RR, Evans WJ. Bed rest promotes reductions in walking speed, functional parameters, and aerobic fitness in older, healthy adults. J Gerontol A Biol Sci Med Sci. 2015;70(1):91-6. https://dx.doi.org/10.1093\%2Fgerona\%2Fglu123

5. Kramer CL. Intensive care-unit-acquired weakness. Neurol Clin. 2017;35(4):723-36. https://doi.org/10.1016/j.ncl.2017.06.008

6. Wall BT, Dirks ML, Van Loon LJC. Skeletal muscle atrophy during shortterm disuse: Implications for age-related sarcopenia. Ageing Res Rev. 2013;12(4):898-906. http://dx.doi.org/10.1016/j.arr.2013.07.003

7. Gingrich A, Volkert D, Kiesswetter E, Thomanek M, Bach S, Sieber CC, et al. Prevalence and overlap of sarcopenia, frailty, cachexia and malnutrition in older medical inpatients. BMC Geriatr. 2019;19:1-10. https://doi.org/10.1186/s12877-019-1115-1

8. Pu L, Zhu B, Jiang L, Du B, Zhu X, Li A, et al. Weaning critically ill patients from mechanical ventilation: A prospective cohort study. J Crit Care. 2015;30(4):862.e7-862.e13. http://dx.doi.org/10.1016/j.jcrc.2015.04.001

9. Woo HY, Oh SY, Lee H, Ryu HG. Evaluation of the association between decreased skeletal muscle mass and extubation failure after longterm mechanical ventilation. Clin Nutr. 2019. https://doi.org/10.1016/j. clnu.2019.12.002
10. Zamora VEC, Cruz MR. Polineuromiopatia do paciente crítico: uma revisão da literatura. Rev Hosp Univ Pedro Ernesto. 2013;12(3):11829. https://doi.org/10.12957/rhupe.2013.7539

11. Martone AM, Bianchi L, Abete P, Bellelli G, Bo M, Cherubini A, et al. The incidence of sarcopenia among hospitalized older patients: results from the Glisten study. J Cachexia Sarcopenia Muscle. 2017;8(6):907-14. https://dx.doi.org/10.1002\%2Fjcsm.12224

12. Puthucheary ZA, Rawal J, McPhail M, Connolly B, Ratnayake G, Chan $P$, et al. Acute skeletal muscle wasting in critical illness JAMA. 2013;310(15):1591-600. https://dx.doi.org/10.1001/ jama.2013.278481

13. Bragança RD, Ataíde TBLS, Mourão LMB, Pinho NCA, Santana MN, Ravett CG, et al. Intensive care unit acquired weakness, handgrip strength, and mortality in critically ill patients. J Crit Care. 2017:42:388-9. https://doi.org/10.1016/j.jcrc.2017.09.056

14. Norman K, Otten L. Financial impact of sarcopenia or low muscle mass - A short review. Clin Nutr. 2019;38(4):1489-95. https://doi. org/10.1016/j.clnu.2018.09.026

15. Brennan P, Perola M, van Ommen GJ, Riboli E. Chronic disease research in Europe and the need for integrated population cohorts. Eur J Epidemiol. 2017;32(9):741-9. https://doi.org/10.1007/s10654-017-0315-2

16. Jang MH, Shin MJ, Shin YB. Pulmonary and physical rehabilitation in critically ill patients. Acute Crit Care. 2019;34(1):1-13. https://doi. org/10.4266/acc.2019.00444

17. Lima JT de, Silva RFA da, Assis AP de, Silva A. Lista de verificação para gerenciamento do despertar diário de pacientes críticos. Rev Bras Ter intensiva. 2019;31(3):318-25. http://dx.doi.org/10.5935/0103507x.20190057

18. Duarte YA de O, de Andrade CL, Lebrão ML. O índex de Katz na avaliação da funcionalidade dos idosos. Rev da Esc Enferm. 2007;41(2):317-25. http://dx.doi.org/10.1590/S0080-62342007000200021 
19. Mehta KM, Pierluissi E, Boscardin WJ, Kirby KA, Walter LC, Chren MM, et al. A clinical index to stratify hospitalized older adults according to risk for new-onset disability. J Am Geriatr Soc. 2011;59(7):1206-16. https://doi.org/10.1111/j.1532-5415.2011.03409.x

20. Hermans G, Clerckx B, Vanhullebusch T, Segers J, Vanpee G, Robbeets C, et al. Interobserver agreement of medical research council sum score and handgrip strength in the intensive care unit. Muscle Nerve. 2012;45(1):18-25. https://doi.org/10.1002/mus.22219

21. Damluji AA, Forman DE, van Diepen S, Alexander KP, Page RL, Hummel SL, et al. Older Adults in the Cardiac Intensive Care Unit: Factoring Geriatric Syndromes in the Management, Prognosis, and Process of Care: A Scientific Statement From the American Heart Association. Circulation. 2020;141(2):e6-e32. https://doi.org/10.1161/ cir.0000000000000741

22. Guidet B, Vallet H, Boddaert J, de Lange DW, Morandi A, Leblanc $\mathrm{G}$, et al. Caring for the critically ill patients over 80: a narrative review. Ann Intensive Care. 2018;8. https://doi.org/10.1186/ s13613-018-0458-7

23. Pérez-Zepeda MU, Sgaravatti A, Dent E. Sarcopenia and post-hospital outcomes in older adults: A longitudinal study. Arch Gerontol Geriatr. 2017;69:105-9. http://dx.doi.org/10.1016/j.archger.2016.10.013

24. Marchiori GF, Tavares DM dos S. Changes in frailty conditions and phenotype components in elderly after hospitalization. Rev Lat Am Enfermagem. 2017;25:e2905. https://doi.org/10.1590/15188345.1417.2905
25. Ramírez-Vélez R, Correa-Bautista JE, García-Hermoso A, Cano CA, Izquierdo $M$. Reference values for handgrip strength and their association with intrinsic capacity domains among older adults. J Cachexia Sarcopenia Muscle. 2019;10(2):278-86. https://dx.doi.org/10.1002\%2Fjcsm.12373

26. Chlan LL, Tracy MF, Guttormson J, Savik K. Peripheral muscle strength and correlates of muscle weakness in patients receiving mechanical ventilation. Am J Crit Care. 2015;24(6):e91-8. https://doi.org/10.4037/ajcc2015277

27. Muscedere J, Waters B, Varambally A, Bagshaw SM, Boyd JG, Maslove D, et al. The impact of frailty on intensive care unit outcomes: a systematic review and meta-analysis. Intensive Care Med. 2017;43(8):1105-22. https://doi.org/10.1007/s00134-017-4867-0

28. de Hoogt PA, Reisinger KW, Tegels JJW, Bosmans JWAM, Tijssen F, Stoot JHMB. Functional Compromise Cohort Study (FCCS): Sarcopenia is a Strong Predictor of Mortality in the Intensive Care Unit. World J Surg. 2018;42:1733-41. https://doi.org/10.1007/s00268-017-4386-8

29. Kou HW, Yeh CH, Tsai H, Hsu CC, Hsieh YC, Chen WT, et al. Sarcopenia is an effective predictor of difficult-to-wean and mortality among critically ill surgical patients. PLoS One. 2019;14(8):e0220699. https:// doi.org/10.1371/journal.pone.0220699

30. Silva-Cruz AL, Velarde-Jacay K, Carreazo NY, Escalante-Kanashiro R. Risk factors for extubation failure in the intensive care unit. Rev Bras Ter Intensiva. 2018;30(3):294-300. https://dx.doi.org/10.5935\%2F0103-507X.20180046

31. Toptas M, Yalcin M, Akkoc E, Demir E, Metin C, Savas Y, et al. The relation between sarcopenia and mortality in patients at intensive care unit. Biomed Res Int. 2018;2018:5263208. https://doi.org/10.1155/2018/5263208 